\title{
PHYTOCHEMICAL SCREENING, ANTIMICROBIAL ACTIVITY AND BRINE SHRIMP LETHALITY BIOASSAY OF DIFFERENT EXTRACTS OF ALYSICARPUS VAGINALIS VAR. NUMMULARIFOLIUS (DC.) MIQ. (FAMILY: FABACEAE)
}

\author{
SUSAN KURIAN*, V. S. JOSEKUMAR \\ Department of Zoology, Mar Ivanios College (Autonomous), Thiruvananthapuram 695015, Kerala, India \\ Email: susankurianmic@gmail.com
}

Received: 15 Oct 2016 Revised and Accepted: 23 Nov 2016

\section{ABSTRACT}

Objective: To evaluate the antimicrobial activity and cytotoxicity of hexane, ethyl acetate and methanol extracts of Alysicarpus vaginalis var. nummularifolius (DC) along with phytochemical analysis.

Methods: The crude extract of hexane (AVH), ethyl acetate (AVE) and methanol (AVM) of Alysicarpus vaginalis var. nummularifolius (DC) were prepared and analysed for phytochemical constituents using standard methods. The cytotoxicity activity of the plant extracts was predicted using brine shrimp lethality assay (BSLA). The antimicrobial activity and the minimal inhibitory concentration (MIC) of the plant extracts were examined against 5 bacterial and 2 fungal strains using agar well diffusion method, and two fold serial dilution method, respectively.

Results: The phytochemical screening studies showed a higher concentration of saponins, alkaloids, flavonoids, phenols, quinones and terpenoids in AVM than the other two extracts. The $\mathrm{LC}_{50}$ value of AVH and AVE were found to be $900.05 \mu \mathrm{g} / \mathrm{ml}$ and $754.35 \mu \mathrm{g} / \mathrm{ml} \mathrm{respectively} \mathrm{using} \mathrm{BSLA} \mathrm{while}$ that of AVM was $>1000 \mathrm{ug} / \mathrm{ml}$. All the extracts of the plant showed antimicrobial activity against most of the test organisms. The MIC values of AVM were lower than AVE for all the microbial strains except for Pseudomonas aeroginosa where AVE $(107.87 \mu \mathrm{g} / \mathrm{ml})$ exhibited higher value than AVM $(51 \mu \mathrm{g} / \mathrm{ml})$

Conclusion: The present study concluded AVM with a high presence of phytochemicals. The AVE and AVM were found to possess promising antimicrobial activity when compared with the standards. The AVM exhibited lesser toxicity when compared with AVH and AVE.

Keywords: Alysicarpus vaginalis var. nummularifolius (DC), Phytochemical analysis, BSLA, Antimicrobial, Cytotoxicity, Minimum Inhibitory Concentration

(C) 2017 The Authors. Published by Innovare Academic Sciences Pvt Ltd. This is an open access article under the CC BY license (http://creativecommons.org/licenses/by/4. 0/) DOI: http://dx.doi.org/10.22159/ijpps.2017v9i1.15688

\section{INTRODUCTION}

Plants are the indispensable storehouse of many chemical metabolites. The medicinal value of plants have assumed a more important dimension in the past two decades owing largely to the discovery that extracts from plants contain many minerals, primary metabolites and secondary metabolites with antioxidant potential [1]. Chemical metabolites present in green plants are grouped into primary and secondary metabolites (phytochemicals). Phytochemicals are good sources of medicinal drugs for instance that with antimicrobial effects are used for the treatment of microbial infections $[2,13]$

Alysicarpus vaginalis var. nummularifolius (DC.) Miq. Family: Fabaceae (Leguminosae) which is commonly known as alyce clover, one leaved clover (Malayalam: Nilaorila). It is widely used for various diseases related with kidney, diuretics, leprosy and pulmonary problems [3]. Ethnobotanical research on folklore medicine identified the plant is used for jaundice treatment along with goat milk [4]. Antioxidant and antiproliferative activity were reported with ethanolic extract of $A$. vaginalis [5]. Hepatoprotective activity was attributed to an ethanolic extract of $A$. vaginalis in experimental rats with nitrobenzene-induced hepatic damage [6]. Different varieties of $A$. vaginalis have been identified.

Many bioactive compounds are isolated from plant resources, however, the status of them as medicinal drugs required thorough screening [7, 8]. Though many medicinal properties of Alysicarpus vaginalis var. nummularifolius (DC.) are reported, a systematic investigation to identify cytotoxicity of this plant resource viz., hexane, ethyl acetate and methanolic extracts is not yet done. Brine shrimp lethality assay (BSLA) is an in vitro toxicity assay which is useful for assessing the toxicity of bioactive compounds from plant extracts. This plant could be a valuable resource with many pharmacological activities especially as an antimicrobial agent. Phytochemical analysis along with antimicrobial screening of various extracts of this plant is suggested to assess its potential as a medicinal herb. Cytotoxicity screening is also essentially important to identify it for human consumption.

\section{MATERIALS AND METHODS}

\section{Collection of plant materials}

Alysicarpus vaginalis var. nummularifolius (DC.) Miq was collected from Nalanchira, Thiruvananthapuram, Kerala, India. It is a common creeping herb found in open ground and waste land; widely distributed in India, Sri Lanka, Pakistan, Africa and Australia. The leaves are obovate-oblong, obtuse at both ends and having a diameter of $1-2.5 \mathrm{~cm}$. Its flowers are pink in dense racemes. They flower and fruit during the month of September to January. The plant specimen was authenticated by Dr. G. Valsaladevi, Curator, Department of Botany, University of Kerala, Kariavattom, Thiruvananthapuram, Kerala. The voucher specimen has been deposited in the Herbarium of Department of Botany, the University of Kerala with voucher no KUBH-5928 for future reference.

\section{Chemicals and reagents}

Hexane, ethyl acetate, methanol, dimethylsulfoxide (DMSO), hydrochloric acid, Dragendorff reagent, Mayer's reagent, Wagner's reagent, Benedict's reagent, sulphuric acid, ferric chloride, sodium hydroxide, lead acetate, ninhydrin, nitric acid, $\alpha$-naphthol, chloroform, glacial acetic acid, potassium dichromate, nutrient agar medium, Potato dextrose agar were purchased from Himedia Chemical: India. All the chemicals and solvents used were of standard analytical grades. 


\section{Preparation of the plant extracts}

The entire fresh plant materials were collected washed and shade dried. The dried plant materials were grinded to a fine powder using an electric grinder. The dried and powdered plant material was successively extracted with hexane (AVH), ethyl acetate (AVE) and methanol (AVM) in the order of their increasing polarity in soxhlet apparatus until it became colourless according to the standard methods [9]. Each extract was concentrated by using rotary vacuum evaporator (Superfit, ROTAVAP PBU-6) and stored in the refrigerator for further analysis.

The extract obtained with each solvent was weighed and the percentage yield was calculated in terms of dried weight of the plant material using the formula:

$\%$ Yield $=$ (Dry weight of the extract/Dry weight of leaf sample) $\mathrm{x}$ 100 . The colour and consistency of the extracts were also noted.

\section{Phytochemical screening}

The plant extracts were analysed for the presence of alkaloids, saponin, flavonoids, phenol, carbohydrates, proteins and amino acids, cardiac glycosides, steroids, anthraquinone and terpenoids using the standard methods [9-11].

\section{Cytotoxicity study: brine shrimp lethality assay (BSLA)}

BSLA was used to predict the cytotoxicity activity of hexane, ethyl acetate and methanol extract of the plant. The cysts of brine shrimp were obtained as a gift from Central Marine Fisheries Research Institute, Vizhinjam, Thiruvananthapuram. The cysts were hatched in filtered and well-aerated sea water under illumination. After $24 \mathrm{~h}$ the nauplii (larva) hatched, and the phototropic nauplii were collected by pipette. The extracts were dissolved in DMSO and diluted with sea water. An alternative dilution method was adopted in the preparation of the different dilutions of the plant extract and the final concentrations were $1000,100,10$ and $1(\mu \mathrm{g} / \mathrm{ml})$. Three replicates in each concentration were done. Potassium dichromate and DMSO of the same concentrations were used as positive and negative controls respectively.

The solutions were added to the pre-marked vials containing 10 brine shrimp nauplii in $5 \mathrm{ml}$ simulated seawater. Dry yeast suspensions were added as food to each vial and maintained under illumination. After $24 \mathrm{~h}$ the survived nauplii in each vial was counted using a magnifying glass. The percentage of mortality of brine shrimp nauplii was calculated for each concentration and compared with positive and negative controls [12]. Since the mortality was observed only in $1000 \mu \mathrm{g} / \mathrm{ml}$ concentration of $\mathrm{AVH}$ and AVE, the further assay was conducted using varying concentrations between 100 and $1000 \mu \mathrm{g} / \mathrm{ml}$ for calculating $\mathrm{LC}_{50}$. Using the probit analysis method described by Finny [13], $\mathrm{LC}_{50}$ and $95 \%$ confidence intervals were determined from the $24 \mathrm{~h}$.

\section{Microbial strains}

Five bacterial strains [Staphyllococcus aureus (ATCC 25923), Sreptococcus mutans (MTCC 890), Escherichia coli (ATCC 25922), Klebsiella pneumonia (ATCC 13883) and Pseudomonas aeroginosa (ATCC 27853)] and two fungi [Candida albicans (ATCC 10231), and Aspergillus niger (ATCC 16404)] were used. American type culture collection (ATCC) strains were purchased from Himedia while $S$. mutans was obtained from Institute of Microbial Technology (MTECH), Chandigarh.

\section{Antibacterial activity}

The antimicrobial activity of the different extracts of the plant was assayed by agar-well diffusion method as described in NCCLS, 1993 [14]. Petri plates containing $20 \mathrm{ml}$ nutrient agar medium was seeded with bacterial strains. Wells of approximately $10 \mathrm{~mm}$ was bored using a well cutter. Plant extracts were prepared in DMSO (stock: $1 \mathrm{mg} / \mathrm{ml} \mathrm{DMSO}$ ). The plant extracts of 25,50 , and $100 \mu \mathrm{l}$ concentrations were added. Streptomycin $(20 \mu \mathrm{l})$ and DMSO (100 $\mu \mathrm{l})$ were used as positive and negative controls respectively. The plates were then incubated at $37{ }^{\circ} \mathrm{C}$ for $24 \mathrm{~h}$. The antimicrobials present in the plant extract are allowed to diffuse out into the medium and interact with the test organisms in the freshly seeded plate. The diameter of the zone of inhibitions was measured in millimetres after $24 \mathrm{~h}$.

\section{Antifungal activity}

The potato dextrose agar plates were prepared and inoculated with a fungal culture. Wells of approximately $10 \mathrm{~mm}$ was bored using a well cutter and samples of different concentration was added. The zone of inhibition was measured in millimetres after overnight incubation and compared with that of standard antimycotic (Clotrimazole) $(10 \mu \mathrm{l})$ which was used as positive control and DMSO $(10 \%)$ as the negative control.

The percentage of inhibition (\% I) was calculated by using the following formula:

$$
\text { Inhibition (\%) = (Zone of Inhibition of extract/ }
$$

Zone of inhibition of the positive control) X 100.

The diameter of the test sample of $100 \mu$ l concentration of various plant extracts was taken for calculating the inhibition $\%$.

\section{Minimal inhibitory concentration (MIC)}

Minimal inhibitory concentration (MIC) of the ethyl acetate and methanol extracts was determined by using two-fold serial dilution methods in 96-well plates against S. mutans, E. coli, P. aeroginosa, $K$. pneumoniae, C. albican and A. niger. Samples were dissolved in DMSO to a final concentration of $1 \mathrm{mg} / \mathrm{ml}$ and added in increasing concentration such as $6.25,12.5,25,50,100 \mu \mathrm{g} / \mathrm{ml}$ respectively. Solvent control was prepared with DMSO (10\%), and blank control was prepared from virgin media. The plates were prepared in triplicates and incubated overnight at $37^{\circ} \mathrm{C}$. Growth was observed by visual inspection and by measuring the optical density (OD) at $620 \mathrm{~nm}$ using microplate reader (ERBA, Germany, Model: ELISCAN $\mathrm{FT}_{3}, 1 \times 96$ wells). The $\mathrm{OD}$ was measured immediately after the visual reading. The growth inhibition for the test wells at each plant extract dilution was determined by the formula:

$$
\text { Percent inhibition }=(\text { OD of control }- \text { OD of test }) /
$$$$
\text { (OD of control) } \times 100 \%
$$

Spectrophotometric MICs were calculated based on the density of the growth control and the lowest drug concentrations that resulted in a $50 \%$ reduction in growth was compared with that of the drugfree growth control [15].

\section{Statistical analysis}

Experimental results were expressed in mean \pm standard error mean (SEM) of the triplicates. Statistical analysis was performed by one-way analysis of variance (ANOVA) followed by Duncan's multiple range test (DMRT) using SPSS software package (version 16). $\mathrm{P}$ value $<0.01$ was considered as significant at $1 \%$ level.

\section{RESULTS}

The present investigation shows the phytochemical analysis, antimicrobial activity and cytotoxicity assay of the different extract of the plant Alysicarpus vaginalis var. nummularifolius (DC). The yield $\%$ of the successive extraction of hexane, ethyl acetate and methanol were $1.3 \%, 4.28 \%$ and $5.12 \%$ respectively. They were a light green solid powder (AVH), brown waxy (AVE) and greenish brown waxy (AVM) in appearance.

\section{Phytochemical analysis}

Various phytochemical analyses with the plant extracts showed the presence of alkaloids, saponin, flavonoids, phenol, carbohydrates, proteins and amino acids, cardiac glycosides, steroids, anthraquinone and terpenoids (table 1). The phytochemical test of the crude hexane $(\mathrm{AVH})$ revealed the presence of tannin, flavonoids, steroids and terpenoids while ethyl acetate (AVE) and methanol (AVM) extract showed the presence of proteins, amino acids, cardiac glycosides, alkaloids, tannins, flavonoids, steroids, quinines and terpenoids. The methanol extract (AVM) showed the higher concentration of saponins, alkaloids, flavonoids, phenols, quinones and terpenoids than the other two extracts. 
Table 1: Phytochemical screening of hexane (AVH), Ethyl acetate (AVE) and Methanol (AVM) extract of Alysicarpus vaginalis var. nummularifolius (DC.)

\begin{tabular}{|c|c|c|c|c|c|}
\hline S. No. & Phytochemical constituent & Test performed & AVH & AVE & AVM \\
\hline \multirow[t]{2}{*}{1} & Saponin & 1. Froth Test & - & - & ++ \\
\hline & & 2. Foam Test & - & - & ++ \\
\hline \multirow[t]{3}{*}{2} & Carbohydrate & 1. Molisch's Test & + & + & + \\
\hline & & 2. Benedict's Test & _- & _- & - \\
\hline & & 3. Fehling's Test & - & - & - \\
\hline \multirow[t]{2}{*}{3} & Protein and Amino acid & 1. Xanthoprotec Test & - & + & + \\
\hline & & 2. Ninhydrin Test & - & _- & + \\
\hline 4 & Cardiac glycosides & Keller Kelliani's Test & ++ & ++ & ++ \\
\hline \multirow[t]{3}{*}{5} & Alkaloids & 1. Wagner's Test & - & - & + \\
\hline & & 2. Mayer's Test & - & + & ++ \\
\hline & & 3. Dragondroff Test & + & _- & ++ \\
\hline 6 & Tannin & Braymer's Test & + & + & ++ \\
\hline \multirow[t]{2}{*}{7} & Flavanoids & 1. Alkaline reagent Test & + & ++ & + \\
\hline & & 2. Lead acetate & + & _- & ++ \\
\hline 8 & Phenol & Ferric chloride Test & + & + & ++ \\
\hline 9 & Steroids & Salkawski's Test & ++ & + & ++ \\
\hline 10 & Anthraquinone & Borntrager's Test & _- & + & _- \\
\hline 11 & Quinones & Hydrochloric Acid & + & + & ++ \\
\hline 12 & Terpenoids & Salkawski's Test & ++ & + & ++ \\
\hline
\end{tabular}

++= Highly present; += Moderately present; -= Absent

\section{Brine shrimp lethality assay (BSLA) for cytotoxicity}

The brine shrimp lethality assay of the three plant extracts was found to be concentration dependent (table 2). The $\mathrm{LC}_{50}$ value of AVH and AVE found to be $900.05 \mu \mathrm{g} / \mathrm{ml}$ and $754.35 \mu \mathrm{g} / \mathrm{ml}$ respectively. Meyer et al. [16] suggested that crude plant extract is considered toxic (active) if it has an $\mathrm{LC}_{50}$ value of less than 1000 $\mu \mathrm{g} / \mathrm{ml}$ while non-toxic (inactive) if it is greater than $1000 \mu \mathrm{g} / \mathrm{ml}$. The methanolic plant extract of Alysicarpus vaginalis var. nummularifolius (DC.) showed no lethality up to $1000 \mu \mathrm{g} / \mathrm{ml}$. Hence its $\mathrm{LC}_{50}$ value is insignificant. While Potassium dichromate which was used as standard showed $\mathrm{LC}_{50}$ value as $24.8 \mu \mathrm{g} / \mathrm{ml}$.

Table 2: Brine shrimp lethality assay of different extracts of Alysicarpus vaginalis var. nummularifolius (DC.) after $24 \mathrm{~h}$

\begin{tabular}{lll}
\hline Plant extracts & LC $\mathbf{5 0}(\boldsymbol{\mu g} / \mathbf{m l})$ & 95\% Confidence interval \\
\hline Potassium Dichromate & 24.8 & $14-37$ \\
AVH & 900.05 & $849.80-965.36$ \\
AVE & 754.35 & $724.93-786.51$ \\
AVM & $>1000$ & \\
\hline
\end{tabular}

Table 3: Antimicrobial activity of Alysicarpus vaginalis var. nummularifolius (DC.) extracts using disc diffusion assay

\begin{tabular}{|c|c|c|c|c|}
\hline \multirow{2}{*}{$\begin{array}{l}\text { Microbial strains } \\
\text { Staphyllococcus aureus }\end{array}$} & \multicolumn{4}{|c|}{ Diameter of inhibition zone (mm) } \\
\hline & $25 \mu \mathrm{l}$ & $50 \mu \mathrm{l}$ & $100 \mu \mathrm{l}$ & Streptomycin $(20 \mu \mathrm{l})$ \\
\hline Hexane & $12.1 \pm 0.05$ & $13.2 \pm 0.05$ & $21.23 \pm 0.03$ & $41 \pm 0.14$ \\
\hline Ethyl acetate & $11.23 \pm 0.06$ & $14.3 \pm 0.05$ & $16.23 \pm 0.08$ & $40 \pm 0.07$ \\
\hline Methanol & $12.3 \pm 0.05$ & $19.33 \pm 0.18$ & $22.26 \pm 0.08$ & $44 \pm 0.06$ \\
\hline \multicolumn{5}{|l|}{ Sreptococcus mutans } \\
\hline Hexane & $10.3 \pm 0.05$ & $12.33 \pm 0.12$ & $15.3 \pm 0.05$ & $49.3 \pm 0.00$ \\
\hline Ethyl acetate & $11.23 \pm 0.03$ & $13.3 \pm 0.05$ & $16.23 \pm 0.08$ & $40.3 \pm 0.05$ \\
\hline Methanol & $12.3 \pm 0.05$ & $12.16 \pm 0.03$ & $15.33 \pm 0.08$ & $44.5 \pm 0.05$ \\
\hline \multicolumn{5}{|l|}{ Escherichia coli } \\
\hline Hexane & Nil & $13 \pm 0.04$ & $14.16 \pm 0.16$ & $39.2 \pm 0.15$ \\
\hline Ethyl acetate & $10.1 \pm 0.05$ & $12.03 \pm 0.03$ & $14.1 \pm 0.1$ & $35.23 \pm 0.18$ \\
\hline Methanol & $10.03 \pm 0.03$ & $11.10 \pm 0.1$ & $12.16 \pm 0.08$ & $38.13 \pm 0.13$ \\
\hline \multicolumn{5}{|l|}{ Klebsiella pneumonia } \\
\hline Hexane & $12.1 \pm 0.05$ & $13.2 \pm 0.05$ & $21.23 \pm 0.03$ & $41 \pm 0.03$ \\
\hline Ethyl acetate & $11.23 \pm 0.06$ & $12.3 \pm 0.06$ & $16.23 \pm 0.08$ & $40.03 \pm 0.03$ \\
\hline Methanol & $12.3 \pm 0.05$ & $11.3 \pm 0.18$ & $22.26 \pm 0.08$ & $44.13 \pm 0.13$ \\
\hline \multicolumn{5}{|l|}{ Pseudomonas aeroginosa } \\
\hline Hexane & $12.13 \pm 0.03$ & $16.4 \pm 0.04$ & $20.3 \pm 0.17$ & $40.5 \pm 0.28$ \\
\hline Ethyle acetate & $10.03 \pm 0.03$ & $14.3 \pm 0.05$ & $20.23 \pm 0.23$ & $40.16 \pm 0.08$ \\
\hline Methanol & $10.23 \pm 0.23$ & $12.2 \pm 0.21$ & $16.33 \pm 0.18$ & $44.0 \pm 0.05$ \\
\hline Candida albicans & & & & Clotrimazole $(20 \mu \mathrm{l})$ \\
\hline Hexane & Nil & $10.1 \pm 0.05$ & $10.7 \pm 0.05$ & $29.96 \pm 0.08$ \\
\hline Ethyl acetate & $12.2 \pm 0.05$ & $13.16 \pm 0.12$ & $19 \pm 0.05$ & $31.93 \pm 0.06$ \\
\hline Methanol & $12.3 \pm 0.06$ & $16 \pm 0.5$ & $21 \pm 0.05$ & $35.03 \pm 0.08$ \\
\hline \multicolumn{5}{|l|}{ Aspergillus niger } \\
\hline Hexane & $10 \pm 0.00$ & $11.13 \pm 0.03$ & $13.13 \pm 0.13$ & $30.9 \pm 0.05$ \\
\hline Ethyl acetate & $11.2 \pm 0.05$ & $14.23 \pm 0.03$ & $26 \pm 0.15$ & $29.93 \pm 0.08$ \\
\hline Methanol & $10.2 \pm 0.05$ & $11.46 \pm 0.27$ & $12.2 \pm 0.20$ & $30.36 \pm 0.31$ \\
\hline
\end{tabular}

Values are mean inhibition zone $(\mathrm{mm}) \pm \mathrm{SE}$ of three replicates 
According to Moshi et al. [17], the brine shrimp results were interpreted as follows: $\mathrm{LC}_{50}<1.0 \mu \mathrm{g} / \mathrm{ml}$-highly toxic; $\mathrm{LC}_{50}-1.0$ $10.0 \mu \mathrm{g} / \mathrm{ml}$-toxic; LC $\mathrm{L}_{50} \quad 10.0-30.0 \mu \mathrm{g} / \mathrm{ml}$-moderately toxic; $\mathrm{LC}_{50}>30<100 \mu \mathrm{g} / \mathrm{ml}$ as non-toxic. The hexane, ethyl acetate and methanol extract of $A$. vaginalis which is having the $\mathrm{LC}_{50}$ value greater than $100 \mu \mathrm{g} / \mathrm{ml}$ can be considered as non-toxic while that of potassium dichromate as moderately toxic. The lethality of the plant extracts to brine shrimps indicated the presence of potent cytotoxic and probably antitumor components of these plants.

\section{Antimicrobial activity}

Plant extracts are generally rich in antimicrobial compounds. The in vitro antimicrobial activity of the different extracts of Alysicarpus vaginalis var. nummularifolius (DC.) under different concentration with the standard are shown (table 3). All the extracts of the plant showed antimicrobial activity against most of the test organisms. The percent of inhibition of different extract is shown in the fig. 1.

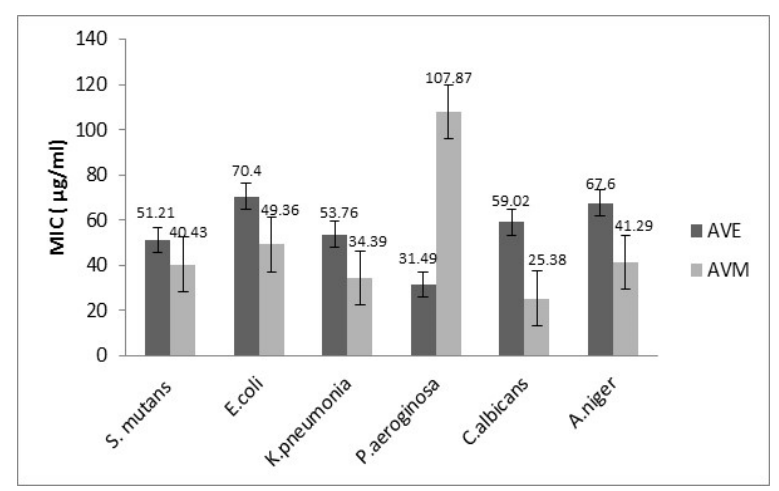

Fig. 1: Minimum inhibitory concentration (MIC) of ethyl acetate (AVE) and methanol (AVM) extract of $A$. vaginalis var. nummularifolius ( $D C$.) against microbial organisms expressed as mean \pm SEM (standard error mean; $n=3$ )

Table 4: Statistical analysis of antimicrobial activity of hexane (AVH), ethyl acetate (AVE) and methanol (AVM) extracts (100 $\mu$ l) of $A$. vaginalis var. nummularifolius (DC.) with respect to various microbial strains

\begin{tabular}{|c|c|c|c|c|c|}
\hline \multirow[t]{2}{*}{ Microbial strains } & \multicolumn{5}{|c|}{ Diameter of inhibition zone(mm) } \\
\hline & AVH & AVE & AVM & $\mathbf{F}$ & $\mathbf{P}$ \\
\hline Staphyllococcus aureus(SA) & $21.23 \pm 0.03^{\mathrm{a}}$ & $16.23 \pm 0.08^{\mathrm{b}}$ & $22.26 \pm 0.08^{\mathrm{c}}$ & 1874.067 & $0.000^{* *}$ \\
\hline Sreptococcus mutans(SM) & $15.3 \pm 0.05^{\mathrm{a}}$ & $16.23 \pm 0.08^{b}$ & $15.33 \pm 0.08^{a}$ & 44.529 & $0.000^{* *}$ \\
\hline Escherichia coli(EC) & $14.16 \pm 0.16^{\mathrm{a}}$ & $14.1 \pm 0.1^{\mathrm{a}}$ & $12.16 \pm 0.08^{b}$ & 84.976 & $0.000^{* *}$ \\
\hline Pseudomonas aeroginosa(PA) & $20.3 \pm 0.17 \mathrm{a}$ & $20.23 \pm 0.23^{\mathrm{a}}$ & $16.33 \pm 0.18^{b}$ & 131.231 & $0.000^{* *}$ \\
\hline Candida albicans(CA) & $10.7 \pm 0.05^{\mathrm{a}}$ & $19 \pm 0.05^{b}$ & $21 \pm 0.05^{c}$ & 894.9 & $0.000^{* *}$ \\
\hline Aspergillus niger(AN) & $13.13 \pm 0.13^{\mathrm{a}}$ & $26.00 \pm 0.15^{b}$ & $12.2 \pm 0.20^{\mathrm{c}}$ & 2199.836 & $0.000^{* *}$ \\
\hline
\end{tabular}

Values are mean \pm SEM (standard error mean) $(n=3)$. ANOVA followed by Duncan's Test. Mean followed by a common letter are not significantly different at the $1 \%$ level $(\mathrm{p}<0.01)$ by Duncan's test

ANOVA showed that there exist significant mean differences in antimicrobial activities among various extracts at $100 \mu \mathrm{l}(\mathrm{P}>0.01)$ (table 4). Duncan's test showed that the inhibition zone of the hexane $(\mathrm{AVH})$ and ethyl acetate (AVE) extracts against $S$. aureus were more or less same ( $P>0.05)$. Methanol extract (AVM) showed highest inhibition zone against $S$. aureus. $(22.26 \pm 0.08) \mathrm{K}$. pneumonia $(21.23 \pm 0.03)$ and $C$. albicans $(21+0.05)$ when compared to hexane $(\mathrm{AVH})$ and ethyl acetate (AVE) extracts. Inhibition zone of the extract AVH $(15.3 \pm 0.05)$ and AVM $(15.33 \pm 0.08)$ against $S$. mutans were more or less the same $(p>0.05)$. AVH and AVE are having a similar reaction and higher zone of inhibition against $E$. coli and $P$. aeroginosa. AVE is having the highest zone of inhibition (26.00 \pm 0.05$)$ against $A$. niger.

The MIC of the AVE and AVM against S. mutans, E. coli, $P$. aeroginosa, K. pneumoniae, $C$. albican and A. niger is shown in the fig. 1. The MIC values of AVE was higher than AVM for all the microbial strains except for $P$. aeroginosa were AVM exhibited higher activity than AVE. The AVE showed the lowest MIC against $P$. aeroginosa i.e. $31.49 \mu \mathrm{g} / \mathrm{ml}$ and higher value for $S$. mutan $(51.21 \mu \mathrm{g} / \mathrm{ml})$, E. coli $(70.4 \mu \mathrm{g} / \mathrm{ml})$, K. pneumonia $(53.76 \mu \mathrm{g} / \mathrm{ml}), C$. albicans $(59.02 \mu \mathrm{g} / \mathrm{ml})$ and A. niger $(67.6 \mu \mathrm{g} / \mathrm{ml})$. AVM showed higher MIC value for $P$. aeroginosa $(107.87 \mu \mathrm{g} / \mathrm{ml})$ while lowest against C. albica ns $(25.38 \mu \mathrm{g} / \mathrm{ml})$.

\section{DISCUSSION}

The aim of the present investigation is to evaluate the different extracts of $A$. vaginalis var. nummularifolius (DC.) for their phytochemical composition, cytotoxicity assay and antimicrobial activity. The detailed literature studies showed that the entire plant of $A$. vaginalis is used in traditional medicine for the treatment of renal calculi [18]; the leaf juice was also used for the improvement of eyesight and ear ache [19]. The root of this plant is widely used for kidneys, diuretics; leprosy and pulmonary troubles [20]. Preliminary phytochemical screening of ethanolic extract of $A$. vaginalis reported the presence of polyphenol [5]. The total phenolic content, total flavonoid content and antioxidant activity of the ethanolic extracts of the plant was evaluated [21]. The free radical scavenging activity and reducing power showed that the plant has significant antioxidant status. The presence of these phytochemicals reveals that the plant will possess various pharmacological activities like anti-inflammatory, anticancer, estrogenic gonadotropic, hepatoprotective functions [21].

More than four different varieties of $A$. vaginalis have been identified. Literature studies reveal that no scientific work have been done on this particular variety of $A$. vaginalis. However, present study is the first ever report on qualitative screening, cytotoxicity study and antimicrobial activity of different extracts of $A$. vaginalis var. nummularifolius (DC.)Miq.

The percent yield of the successive extraction of hexane, ethyl acetate and methanol showed that the methanol extract (AVM) has the highest yield. Studies reveal the presence of the major phytochemicals are in polar fractions $[22,23]$. The preliminary phytochemical analysis of the three extract revealed the presence of alkaloids, flavonoids, tannin, phenol and steroid (table 1). The analysis showed that amongst the three extracts, the polar fraction, methanol (AVM) contain high phenol, flavonoid, alkaloid, saponin, tannin, steroids and terpenoids.

A similar result was reported in the ethanolic extract of $A$. vaginalis revealed the presence of alkaloids, flavonoids, sterols, tannins, polyphenols, and triterpenoids [7]. The HPTLC studies on the petroleum ether extracts of $A$. vaginalis reported the presence of lupeol, beta sitasterol and stigmasterol [24].

All the three extracts were screened for cytotoxicity using brine shrimp lethality assay for $\mathrm{LC}_{50}$. Higher $\mathrm{LC}_{50}$ values indicate a lesser toxicity. Of the three extracts, $\mathrm{LC}_{50}$ value of methanol (AVM) was $>1000$. Hence it is considered purely non-toxic considering Mayers et al. standards of evaluation [16], while $\mathrm{LC}_{50}$ value of $\mathrm{AVH}$ and AVE were $900.05 \mu \mathrm{g} / \mathrm{ml}$ and $754.35 \mu \mathrm{g} / \mathrm{ml}$. The $\mathrm{LC}_{50}$ value of the three extracts can be considered very less toxic to normal cells. The intrinsic functions of the cells may be disturbed if a compound is acutely toxic [25]. A positive correlation was reported between the 
brine shrimp lethality test in mice in medicinal plant research [26]. Hence, the brine shrimp lethality assay of $A$. vaginalis can be considered as an ideal preliminary screening for toxicity in vivo. Antimicrobial activity of plant extract was considered to be good if its MIC was less than $100 \mu \mathrm{g} / \mathrm{ml}$, moderate if MIC was from 100.0 to $500.0 \mu \mathrm{g} / \mathrm{ml}$ and poor over $500.0 \mu \mathrm{g} / \mathrm{ml}$ [27]. Since the MIC of the ethyl acetate and methanol extracts of the plant against all the microbial strains were analysed to be less than $100 \mu \mathrm{g} / \mathrm{ml}$, the antimicrobial activity of the plant extracts can be considered good quality. The antimicrobial potential of the plant extracts could be due to its ability to bind to the cell wall of the bacteria, thereby inhibiting its synthesis probably because of the flavonoids, alkaloids and tannins present in the plant [28].

The flavonoids, alkaloids, tannins, triterpenes and steroids present through phytochemical screening might be responsible for the pharmacological activities of the plant [29]. Alkaloids are widely used for medicinal purposes and have positive and negative effects to human beings $[10,30]$. All these natural phytochemicals possess antioxidant activity [31-33]. The plant extracts showed the $\mathrm{LC}_{50}$ value to be considered very less toxic to normal cells and exhibit a high antimicrobial activity. Due to these reasons, this plant can be identified as a good source for medicinal compounds.

\section{CONCLUSION}

The present study concluded that hexane, ethyl acetate and methanol extract of $A$. vaginalis var. nummularifolius (DC.) showed the presence of various phytochemicals of which methanol extract showed the high presence of alkaloids, phenols, flavonoids, saponins, tannin and terpenoids. Using the brine shrimp lethality assay the plant extracts showed the $\mathrm{LC}_{50}$ value to be considered very less toxic to normal cells. The present study revealed significant antimicrobial activity of the plant extracts when compared with standards. Since the minimum inhibitory concentration of the plant extracts was less than $100 \mu \mathrm{g} / \mathrm{ml}$, the plant was considered to have a very good antimicrobial activity. However, further studies are required to throw light on the biological activity of $A$. vaginalis and its bioactive compounds against various diseases.

\section{ACKNOWLEDGEMENT}

The authors wish to thank the Head, Department of Zoology and the Principal, Mar Ivanios College, Thiruvananthapuram, Kerala, for providing the necessary facilities to do the work. The financial support from the University Grand Commission in the form of Teacher Fellowship under the Faculty Development Programme (No. FIP/12 $2^{\text {th }}$ Plan/KLKE013 TF-08 dt. 09/02/2016) is acknowledged by the first author.

\section{CONFLICT OF INTERESTS}

The authors declare no conflict of interest.

\section{REFERENCES}

1. Akinmoladun AC, Ibukun EO, Afor E, Akinrinlola BL, Onibon TR, Akiinboye 0 , et al. Chemical constituents and antioxidant activity of Alstonis boonei. Afr J Biotechnol 2007;6:1197-201.

2. Gracelin DHS, Britto AJD, Rathnakumar PBJ. Qualitative and quantitative analysis of phytochemicals in five in $P$. teris species. Int J Pharm Sci 2013;5:105-7.

3. Burkill HM. The useful plants of west tropical Africa. Royal Botanic Gardens, Kew 1985;3:9.

4. Saritha B, Brindha P. Review of Ethanopharmacognosy of Justicia tranquebariensis L-A traditional Siddha drug. Int J Pharm Technol 2013;5:467-74.

5. Rathi MA, Meenakshi P, Guru Kumar D, Arul Raj C, Thirumoorthi, L, Gopalakrishnan VK. Potential antioxidant and antiproliferative activities of Alysicarpus vaginalis(L.)DC. J Pharm Res 2010;3:2375-7.

6. Rathi MA, Periasamy M, Gopalakrishnan VK. Hepatoprotective activity of Alysicarpus vaginalis against nitrobenzene-induced hepatic damage in rats. South Indian J Biol Sci 2015;1:60-5.

7. Chandrika M, Chellaram C. Efficacy of antioxidation and antiinflammation of the leaf extracts of Borreria hispida. Int J Pharm Pharm Sci 2016;8:369-72.
8. Seth R, Sarin R. Analysis of the phytochemical content and antimicrobial activity of Jatropha gossypifolia L. Arch Appl Sci Res 2010;2:285-91.

9. Harborne JB, Phytochemical methods. 2nd edition. Chapman and Hall publications, London, New York; 1984. p. 288.

10. Harborne JB. Phytochemical methods. Chapman and Hall, Ltd., London: New York; 1973. p. 49-188.

11. Sofowora A. Screening plants for bioactive agents. Medicinal plants and traditional medicinal in Africa. 2nd Ed. Spectrum Books Ltd, Sunshine House, Ibadan, Nigeria; 1993. p. 134-56.

12. Olowa LF, Olga MN. Brine shrimp lethality assay of the ethanolic extract of three selected species of medicinal plants from Iligan City, Philippines. Int Res J Biol Sci 2013;2:4-77.

13. Finney DJ. Probit analysis. $3^{\text {rd }}$ ed. Cambridge University Press: Cambridge, England; 1971.

14. National Committee for Clinical Laboratory Standards. Performance Standards for Antimicrobial Disk Susceptibility Tests-Fifth Edition: Approved Standard M2-A5. NCCLS, Villanova, PA; 1993a.

15. National Committee for Clinical Laboratory Standards. Reference method for broth dilution antifungal susceptibility testing of yeasts. Approved standard. Document M27-A. National Committee for Clinical Laboratory Standards, Wayne, Pa; 1997.

16. Mayer BN, Ferrigni NR, Putnam JE, Jacobsen DE, Nichols DE, McLaughlin. Brine shrimp: a convenient general bioassay for active plant constituents. Plant Med 1982;45:31-4.

17. Moshi MJ, Innocent E, Magadula JJ, Otieno DF, Weisheit A. Brine shrimp toxicity of some plants used as traditional medicines in Kagera Region, northwestern Tanzania. Tanzania J Health Res 2010;12:63-7.

18. Ediriweera ERHSS. A review on medicinal uses of weeds in Sri Lanka. Trop Agric Res Extension 2007;10:11-6.

19. Tirkey A. Some ethnobotanical plants of the family-Fabaceaeof Chhattisgarh state. J Traditional Knowledge 2006;5:551-3.

20. Burkil HM. Useful plants of west tropical Africa, Vol. 1. A-D. Royal Botanic Gardens, Kew; 1985. p. 960.

21. Rattanata N, Sakda D, Suthep P. Antioxidant and antibacterial properties of selected Thai weed extract. Asian Pac J Trop Biomed 2014;4:890-5.

22. Anokwuru CP, Anyasor GN, Ajibaye O, Fakoy O, Okebugwa P. Effect of extraction solvents in phenolic, flavonoids and antioxidant activities of three Nigirian medicinal plants. Nat Sci 2011;9:53-61.

23. Kumoroa AC, Hasana M, Singh H. Effect of solvent properties on the soxhlet extraction of diterpenoid lactones from Andrographis paniculata leaves. Sci Asia 2009;35:306-9.

24. Pokle DS, Pal SC, Subur KW. Isolation, characterization and quantitation of phytoconstituents from two plants of fabaceae. Asian J Biochem Pharm Res 2012;4:217-33.

25. George M, Josekumar VS. In vitro cytotoxicity screening, phytochemical profile and heavy metal analysis of different extracts of Acrosticum heterophyllum L. Indian J Nat Prod Resour 2016;7:19-24.

26. Logarto PA, Silva YR, Guerra SI, Iglesias BL. Comparative study of the assay of Artemia salina L. and the estimate of the medium lethal dose ( $\mathrm{LC}_{50}$ value) in mice, to determine the acute oral toxicity of plant extracts. Phytomedicine 2001;8:395-400.

27. Dabur R, Gupta A, Mandal TK, Singh DD, Vivek B, Gurav AM, et al. Antimicrobial activity of some Indian medicinal plants. Afr J Tradit Complementary Altern Med 2007;4:313-8.

28. Vital PG, Rivera WL. Antimicrobial activity and cytotoxicity of Chromolaena odorata (L. f.). J Med Plants Res 2009;3:511-8.

29. Chakraborty AK, Rambhade S, Patil UK. Chromolaena odorata(L.): an overview. J Pharm Res Stuart G Santiago AS 2011;4:573-6.

30. Mythili T, Ravindhran R. Phytochemical screening and antimicrobial activity of Sesbania sesban (I) Merr. Asian J Pharm Clin Res 2012;5:179-82.

31. Khatua S, Roy T, Acharya K. Antioxidant and free radical scavenging capacity of phenolic extract from Russula laurocerasi. Asian J Pharm Clin Res 2013;6:156-60. 
32. Paloi S, Acharya K. Evaluation of antioxidative activity and chemical composition of ethanolic extract from Amanita vaginata (Bull.) La. m.: an in vitro study. Asian J Pharm Clin Res 2014;7:88-92.

33. Rajananda ST, Ganga RB, Haritha P. Antioxidant activity and hepatoprotective potential of Balanites roxburghii fruits. Asian J Pharm Clin Res 2015;8:270-3.

\section{How to cite this article}

- Susan Kurian, VS Josekumar. Phytochemical screening antimicrobial activity and brine shrimp lethality bioassay of different extracts of Alysicarpus vaginalis var. nummularifolius (DC.) MIQ. (family: fabaceae). Int J Pharm Pharm Sci 2017;9(1):1-6. 